\title{
UJI EMPIRIK METODE PENGUKURAN HEDGING RATIO DAN EFEKTIVITAS HEDGING DI BURSA KOMODITAS BERJANGKA JAKARTA
}

\author{
THE EMPIRICAL TEST OF THE HEDGE RATIO MEASUREMENT METHOD AND \\ HEDGING EFFECTIVENESS AT JAKARTA COMMODITY FUTURE MARKET
}

\author{
Buddi Wibowo*)1 \\ *) Fakultas Ekonomi dan Bisnis, Universitas Indonesia \\ Kampus UI Depok, Jawa Barat 16424, Indonesia
}

\begin{abstract}
Hedging strategies in the commodity futures market is strongly influenced by the estimation method of hedge ratio. This study examines the effectiveness of hedging strategy against cash position in Indonesia's palm oil spot market using three hedge ratio estimation methods: OLS, Vector Error Correction Model, and Threshold-ARCH. The results show the hedging effectiveness in the Jakarta Futures Exchange is considerably highly effective to reduce the impact of fluctuations of spot price. The effectiveness of hedging strategy using OLS as the simplest method is close to VECM method and TARCH. The effectiveness of hedging strategy using OLS hedge ratio provides an opportunity for market player in implementing hedging strategy in Jakarta Futures Exchange due to its simplicity in estimation procedure
\end{abstract}

Keywords: hedge ratio, hedging effectiveness, OLS, VECM, TARCH

\begin{abstract}
Abstrak: Strategi lindung nilai di bursa berjangka komoditas sangat dipengaruhi oleh metode penetapan hedge ratio. Penelitian ini menguji efektivitas yang dihasilkan dari beberapa metode penetapan hedge ratio untuk melindung nilai posisi kas di pasar spot komoditas minyak sawit di Indonesia dengan menggunakan kontrak Futures di bursa berjangka. Metode penentuan hedge ratio yang diuji adalah metode OLS, Vector Error Correction Model, dan Threshold-ARCH. Hasil penelitian ini menunjukkan efektivitas lindung nilai di Bursa Berjangka Jakarta cukup efektif mengurangi dampak fluktuasi harga spot. Efektivitas lindung nilai dengan metode OLS yang paling sederhana tidak terpaut terlampau jauh dengan metode VECM dan TARCH. Efektivitas lindung nilai dengan metode OLS memberikan peluang implementasi strategi lindung nilai di Bursa Berjangka Jakarta karena kesederhanaannya dalam prosedur estimasi hedge ratio.
\end{abstract}

Kata kunci: hedge ratio, efektivitas lindung nilai, OLS, VECM, TARCH

${ }^{1}$ Corresponding author:

Email: buddi.wibowo@ui.ac.id

\section{PENDAHULUAN}

Satu dekade terakhir harga pangan mengalami kenaikan volatilitas yang cukup signifikan (Roache, 2010; Wright, 2011). Fluktuasi harga yang tinggi tidak hanya terjadi pada bahan makanan pokok, tetapi juga bahan pangan penopang seperti minyak goreng yang digunakan sebagian besar penduduk Asia untuk memasak. Bellemare (2011) menunjukkan kenaikan harga pangan menjadi faktor utama munculnya keresahan dan kerusuhan di berbagai negara. Menemukan cara lindung nilai (hedging strategy) yang efektif menjadi sangat penting, tidak saja bagi para petani atau pengusaha agribisnis. Namun, juga bagi ketahanan ekonomi, politik dan sosial suatu negara. Harga pangan telah menjadi salah satu instrumen politik yang sentral dalam setiap kampanye politik.

Galtier (2013) menunjukkan ada dua pendekatan yang digunakan oleh negara-negara di dunia untuk menjaga stabilitas harga pangan: intervensi harga langsung di pasar dengan mengatur jumlah supply atau dengan memfasilitasi sistem penciptaan harga (price discovery) melalui pasar komoditas berjangka. Dengan demikian, proses terjadinya harga dapat lebih terkontrol oleh seluruh pihak yang berkepentingan (stakeholder). Pendekatan pertama, yaitu menciptakan stabilitas harga dengan menjaga keseimbangan kompensasi antara 
produsen bahan pangan/petani dengan konsumen melalui pengawasan dan penjagaan logistik bahan bangan tersebut antara wilayah yang surplus dengan yang defisit serta antara waktu panen dengan jumlah supply yang melimpah dan dengan waktu paceklik atau waktu tanam yang kekurangan stok dalam jumlah besar. Metode penjagaan stabilitas harga diterjemahkan menjadi strategi penjagaan stok dan pelepasannya ke pasar pada waktu yang tepat. Pendekatan ini menjadi pendekatan yang paling konvensional dan terbukti cukup efektif di beberapa negara. Pergerakan harga pangan selengkapnya pada Tabel 1 .

Pendekatan kedua adalah dengan mengurangi ketidakstabilan harga melalui mekanisme penciptaan harga (price discovery) di pasar komoditas berjangka. future exchanges memberikan fasilitas bagi semua pihak yang berkepentingan dalam proses terbentuknya harga pada saat delivery barang (spot price) dengan menyepakati terlebih dahulu perjanjian futures contract yang menetapkan besarnya harga (future price) dan banyaknya barang (quantity) jauh hari sebelum tanggal delivery. Bagi produsen, adanya harga jual yang telah disepakati mengurangi ketidakpastian pendapatan. Produsen dapat lebih fokus pada proses produksi sehingga dapat memenuhi jumlah kuantitas barang sekaligus kualitasnya sesuai dengan isi kontrak futures. Konsumen memperoleh kepastian harga dan dapat melakukan lindung nilai (hedging) terhadap volatilitas harga spot.

Pendekatan kedua yang menggunakan mekanisme pasar komoditas berjangka menjadi cara yang digunakan di negara-negara maju dimana harga pasar pangan diserahkan ke mekanisme pasar namun tetap dapat memelihara keseimbangan benefit bagi produsen dan konsumen. Tantangan terbesar untuk mengimplementasikan mekanisme pasar komoditas berjangka adalah ada edukasi seluruh pemangku kepentingan karena bursa berjangka dan kontrak futures yang diperdagangkan di dalamnya merupakan institusi baru yang belum dipahami secara luas oleh masyarakat. Masyarakat perlu diedukasi bagaimana memanfaatkan kontrak futures sebagai perangkat lindung nilai (hedging) yang efektif sekaligus efisien/ murah. Riset-riset ilmiah dibutuhkan untuk dapat mengungkap berbagai alternatif metode hedging dan ukuran hedging effectiveness sebagai kriteria pemilihan metode hedging yang terbaik. Hal ini lah yang dilakukan oleh semua negara yang sedang membangun pasar komoditas di dalam negerinya masing-masing demi tercapainya stabilitas harga pangan di dalam negeri mereka masing-masing. Contohnya Gupta dan Singh (2009) di India, serta Fatimah dan Zainalabidin (1991) di Malaysia.

Indonesia adalah produsen terbesar minyak kelapa sawit di dunia dan secara logis seharusnya menjadi negara dengan transaksi kontrak futures atas minyak sawit dan produkturunan nya yang terbesar di dunia pula namun transaksi kontrak futures palm oil lebih banyak terjadi di Kuala Lumpur Malaysia. Data dapat dilihat pada Gambar 1. Ironisnya sampai saat ini harga minyak kelapa sawit dunia justru merujuk kepada harga yang terjadi di bursa komoditas berjangka Kuala Lumpur bukan Jakarta. Hal ini disebabkan tertinggalnya pembangunan dan pengembangan bursa komoditas berjangka di Indonesia. Jakarta Futures Exchange (JFX) adalah bursa berjangka pertama di Indonesia yang berdiri pada tanggal 19 Agustus 1999. Bursa komoditas berjangka Kuala Lumpur beroperasi sejak Oktober 1980. Indonesia terlambat 19 tahun dari Malaysia dalam mengembangkan pasar berjangka untuk komoditas. Salah satu faktor yang menyebabkan tertinggal jauhnya bursa komoditas berjangka Indonesia adalah karena riset-riset berkaitan dengan bursa komoditas berjangka di Indonesia masih minim sekali sehingga masyarakat tidak memiliki panduan dan gambaran apa yang terjadi di dalam bursa komoditas berjangka Indonesia dan bagaimana menggunakannya untuk kepentingan mereka. Riset di bursa komoditas berjangka Malaysia telah sangat banyak sejak jauh hari contohnya: Rosalan (1995), Fatimah dan Zainalabidin (1991), Liew dan Brooks (1998) yang meneliti berbagai strategi hedging, permasalahan dan kemampuan bursa berjangka Malaysia sebagai perangkat pengelolaan risiko.

Fokus strategi hedging adalah penentuan hedge ratio, yaitu proporsi posisi kas yang harus dilindungi dengan sebuah posisi yang berlawanan di bursa berjangka. Dengan mengambil posisi short di bursa berjangka yang berlawanan arah dengan posisi long di pasar spot maka fluktuasi harga di pasar spot dapat diminimalkan dampaknya terhadap portfolio asset yang dimiliki seorang hedger. Risiko berfluktuasinya nilai portfolio asset dapat diminimalkan dengan menggunakan kontrak futures sebagai instrumen hedging. 
Tabel 1. Pergerakan harga pangan

\begin{tabular}{lrrrrrrrrrrr}
\hline & \multicolumn{2}{c}{2012} & \multicolumn{2}{c}{2013} & \multicolumn{2}{c}{2014} & \multicolumn{2}{c}{2015} & \multicolumn{2}{c}{2016} \\
\hline Komoditas & $\begin{array}{c}\text { Rata- } \\
\text { rata } \\
\text { Februari }\end{array}$ & $\begin{array}{c}\text { Rata- } \\
\text { rata } \\
\text { Tahunan }\end{array}$ & $\begin{array}{c}\text { Rata- } \\
\text { rata } \\
\text { Februari }\end{array}$ & $\begin{array}{c}\text { Rata- } \\
\text { rata } \\
\text { Tahunan }\end{array}$ & $\begin{array}{c}\text { Rata- } \\
\text { rata } \\
\text { Februari }\end{array}$ & $\begin{array}{c}\text { Rata- } \\
\text { rata } \\
\text { Tahunan }\end{array}$ & $\begin{array}{c}\text { Rata- } \\
\text { rata } \\
\text { Februari }\end{array}$ & $\begin{array}{c}\text { Rata- } \\
\text { rata } \\
\text { Tahunan }\end{array}$ & $\begin{array}{c}\text { Rata- } \\
\text { rata } \\
\text { Februari }\end{array}$ & $\begin{array}{c}\text { Rata- } \\
\text { rata } \\
\text { Tahunan }\end{array}$ \\
\hline $\begin{array}{l}\text { Beras } \\
\text { Medium }\end{array}$ & 8.153 & 7.951 & 8.449 & 8.303 & 9.220 & 8.656 & 10.480 & 9.494 & 10.920 & 10.690 \\
Daging Sapi & 73.111 & 71.256 & 87.999 & 85.438 & 100.119 & 97.161 & 101.691 & 101.007 & 112.970 & 110.030 \\
Gula Pasir & 10.837 & 10.481 & 12.300 & 12.310 & 11.679 & 11.647 & 11.167 & 11.159 & 13.160 & 13.040 \\
Telur Ayam & 28.352 & 17.129 & 19.583 & 18.212 & 21.535 & 19.689 & 22.947 & 21.968 & 25.250 & 25.310 \\
$\begin{array}{l}\text { Minyak } \\
\text { Goreng }\end{array}$ & 9.782 & 9.595 & 9.947 & 9.156 & 21.535 & 19.689 & 11.276 & 11.290 & 10.470 & 10.360 \\
\hline
\end{tabular}

Sumber: Kementerian Perdagangan Republik Indonesia (2016); Monthly Trade Figure Indonesia, 2012-2016

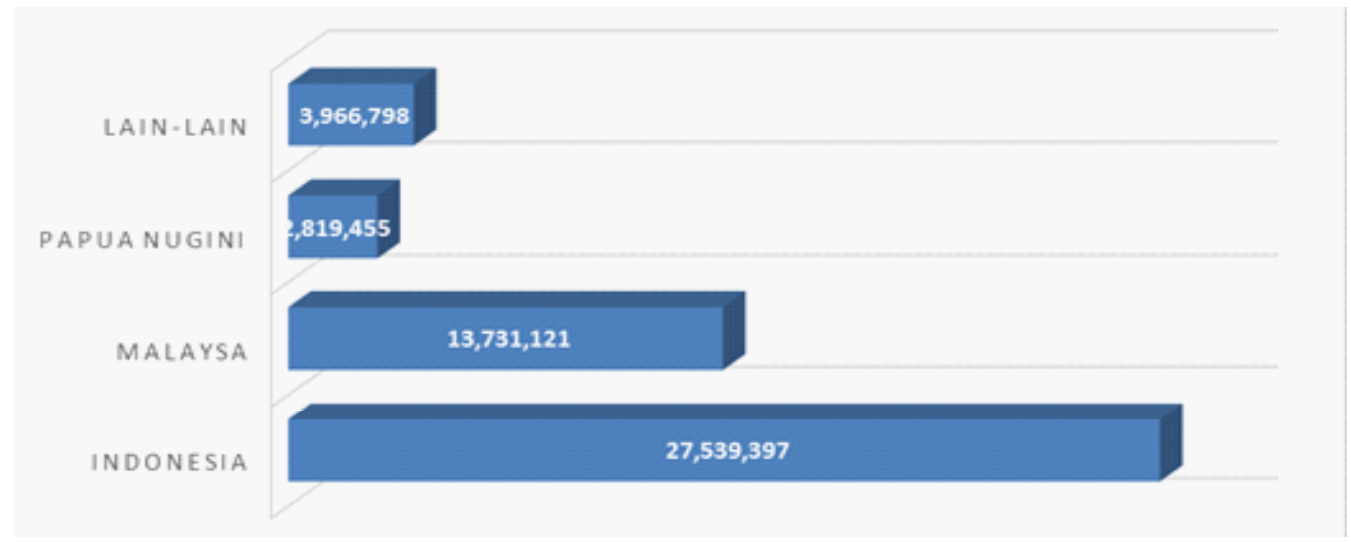

Gambar 1. Produksi minyak sawit dunia (Roundtable of Sustainable Palm Oil, 2016)

Terdapat cukup banyak riset empirik yang berupaya menguji efektivitas lindung nilai di berbagai pasar komoditas berjangka yang ada dengan menggunakan hedge ratio yang diukur dengan beberapa metodologi yang berbeda. Metodologi penentuan hedge ratio terbagi dua kelompok besar yaitu static hedge ratio dan time varying hedge ratio. Static hedge ratio mengasumsikan hubungan antara harga spot dan harga futures bersifat konstan sehingga proporsi antara kuantitas kontrak futures dan posisi kas di pasar spot bersifat konstan pula dan dapat ditentukan untuk periode yang relatif agak panjang. Static hedge ratio yang paling sederhana adalah yang diestimasi dengan menggunakan regresi OLS. Termasuk dalam kategori static hedge ratio adalah hedge ratio yang diestimasi dengan Vector Error Correction Model (VECM) untuk mengatasi persoalan hubungan kointegrasi antara harga spot dan futures yang dapat menyebabkan regresi OLS menjadi spurious regression. Time varying hedge ratio mengasumsikan volatilitas harga spot memiliki korelasi yang berubah-ubah antar waktu dengan volatilitas harga futures. Asumsi dari time varying hedge ratio ini cukup banyak didukung oleh riset-riset sebelumnya seperti yang ditunjukkan oleh Cutter dan Hanly (2012) dan Juhl et al. (2012). Namun, implementasi dari time varying hedge ratio ini membutuhkan biaya yang tidak sedikit karena hedge ratio berubah-ubah setiap titik waktu menyesuaikan perubahan korelasi dari volatilitas harga spot dan futures. Metode penentuan hedge ratio yang bersifat time varying juga relatif lebih kompleks dengan model yang lebih rumit dan membutuhkan keahlian dan pengetahuan tersendiri untuk dapat mengestimasinya seperti Yang dan Allen (2005) yang menggunakan multivariate GARCH dan $\mathrm{Ku}$ et al. (2007) yang menggunakan Dynamic Conditional Correlation (DCC)

Beberapa uji menunjukkan hasil yang menarik, yaitu strategi hedging dengan menggunakan metode penentuan hedge ratio yang sederhana seperti regresi OLS justru memiliki hedging effectivenes yang lebih tinggi dibandingkan apabila menggunakan metode lain yang lebih kompleks (Moschini dan Myers, 2002). Apalagi jika biaya transaksi dan seluruh biaya non ekonomis lainnya seperti tenaga dan waktu untuk mengimplementasikan continuous balancing antara kuantitas kontrak futures dan posisi kas di pasar spot ikut diperhitungkan dalam pengukuran hedging 
effectiveness tersebut. Hal ini ditemukan juga oleh Gupta dan Kaur (2015) di India, Bhargava dan Malhotra (2007) di beberapa negara Asia, dan Lien (2005) di Amerika Serikat dan beberapa negara Eropa. Juhl et al. (2012) menunjukkan efektivitas lindung nilai dalam jangka pendek lebih tinggi dengan menggunakan metode penentuan hedge ratio yang lebih sederhana. Beberapa peneliti menunjukkan bahwa efektivitas hedging selain ditentukan oleh metode pengukuran hedge ratio yang tepat juga dipengaruhi oleh kondisi likuiditas pasar (Gupta dan Singh, 2009) dan perilaku asimetrik dari volatilitas harga spot dan futures (Cotter dan Hanly, 2012). Likuiditas yang rendah menyebabkan harga spot dan futures tidak mencerminkan nilai pasar yang sebenarnya. Sementara, volatilitas yang asimetrik menyebabkan besarnya volatilitas jauh berbeda antara kondisi pasar pada saat yang penuh sentiment positif dengan yang netral dan yang negatif. Alizadeh dan Nomikos (2004) menunjukkan setiap tahap perkembangan pasar komoditas berjangka membutuhkan strategi penentuan hedge ratio yang berbeda.

Riset ini akan mengukur hedge ratio minyak kelapa sawit di Bursa Berjangka Jakarta dengan menggunakan dua metode dengan pendekatan static, yaitu OLS dan VECM dan satu metode time varying hedge ratio yaitu TARCH. VECM digunakan untuk mengatasi masalah cointegration antara harga spot dan futures. TARCH atau Threshhold ARCH digunakan untuk mengantisipasi adanya perilaku asimetrik dari harga spot dan futures. Efektifitas lindung nilai dengan menggunakan ketiga hedge ratio tersebut akan diuji dengan menggunakan ukuran hedging effectiveness yang secara umum digunakan juga pada riset-riset sebelumnya, misalnya Cotter dan Hanly (2012) dan Juhl et al. (2012). Dengan mengungkap efektivitas lindung nilai dengan tiga metode pengukuran hedge ratio yang berbeda, penelitian ini tidak saja menjadi uji empirik yang menambah khazanah pemahaman ilmiah di bursa komoditas berjangka yang relatif kurang likuid seperti di Indonesia. Namun, juga dapat menjadi referensi bagi praktisi dalam menyusun strategi hedging di bursa berjangka Indonesia.

\section{METODE}

Data time series harga Futures minyak kelapa sawit diperoleh dari Jakarta Futures Exchanges. Harga futures adalah harga kontrak futures olein 10 ton jatuh tempo 1 bulan, yang tercatat secara harian di Jakarta Futures Exchanges mulai 1 November 2013 sampai 20 Desember 2016. Data time series harga spot minyak kelapa sawit diperoleh dari Datastream Thomson Reuters. Harga spot harian minyak kelapa sawit yang digunakan adalah harga FOB atau free on board di luar biaya asuransi dan biaya-biaya lainnya.

Analisis hubungan antara data time series harga spot dan harga futures dilakukan dengan menggunakan model regresi time series dengan metode estimasi Ordinary Least Square (OLS), serta model ekonometrik time series seperti cointegration test, VECM dan model volatilitas asimetrik TARCH. Cointegration test digunakan unntuk membuktikan terlebih dahulu keberadaan hubungan kointegrasi antara harga spot dan harga futures sebelum menghitung hedge ratio dengan model VECM. Model TARCH digunakan untuk memodelkan volatilitas harga spot dan harga futures. Ketiga model, OLS, VECM, dan TARCH akan menghasilkan hedge ratio masing-masing yang kemudian diuji efektivitasnya dalam menurunkan volatilitas portofolio asset pada periode selanjutnya dengan menghitung hedging effectiveness setiap hedge ratio seperti yang dirumuskan oleh Juhl et al. (2012) dan Cotter dan Hanly (2012). Komparasi hedging effectiveness antara ketiga hedge ratio dapat mengungkapkan kinerja setiap hedge ratio dan kesesuaiannya dengan kondisi pasar komoditas berjangka Jakarta. Gambar 2 memuat kerangka pikiran penelitian ini serta alur pelaksanaan penelitian.

Strategi lindung nilai dengan menggunakan kontrak futures dengan mengikuti suatu hedge ratio dapat dijelaskan sebagai berikut:

Portofolio investasi yang telah dilindung nilai adalah kombinasi posisi di pasar spot dan pasar futures dapat ditulis sebagai berikut:

$$
\mathrm{V}_{\text {hedged }}=\mathrm{Q}_{\mathrm{S}} \text { Spot Price }-\mathrm{Q}_{\mathrm{F}} \text { Futures Price }
$$

$\mathrm{V}_{\text {hedged }}$ adalah nilai portfolio yang dilindung nilai dengan menggunakan kontrak Futures, $\mathrm{Q}_{\mathrm{S}}$ adalah kuantitas di pasar spot, dan $\mathrm{Q}_{\mathrm{F}}$ adalah kuantitas kontrak Futures yang dipegang.

Strategi lindung nilai yang maksimal adalah ketika perubahan harga pada pasar Spot tidak menyebabkan perubahan sama sekali terhadap nilai portfolio atau

$$
\Delta \mathrm{V}_{\text {hedged }}=0 .
$$


$\Delta \mathrm{V}_{\text {hedged }}=\mathrm{Q}_{\mathrm{S}} \Delta$ Spot Price $-\mathrm{Q}_{\mathrm{F}} \Delta$ Futures Price

Jika $\Delta \mathrm{V}_{\text {hedged }}=0$ maka,

$\mathrm{Q}_{\mathrm{S}} \Delta$ Spot Price $=\mathrm{Q}_{\mathrm{F}} \Delta$ Futures Price (3)

$$
\mathrm{Q}_{\mathrm{F}} / \mathrm{Q}_{\mathrm{S}}=(\Delta \text { Spot } \text { Price }) /(\Delta \text { Future Price })
$$

$\mathrm{Q}_{\mathrm{F}} / \mathrm{Q}_{\mathrm{S}}$ yang dapat menjaga perubahan nilai portfolio asset sama dengan nol disebut maksimal hedge ratio. Setiap orang dapat memilih optimal hedge ratio yang sesuai dengan risk-aversion level masing-masing karena memegang kontrak futures membutuhkan biaya dan setiap orang memiliki preferensi risiko sendirisendiri.

\section{Hedge Ratio OLS, VECM dan TARCH}

Metode perhitungan hedge ratio pada penelitian ini merujuk pada riset sebelumnya seperti Juhl et al. (2012); Cotter dan Hanly (2012); Gupta dan Singh, (2009). Hedge ratio OLS dapat diestimasi dengan menggunakan persamaan regresi time series:

$$
\Delta \operatorname{LogS}_{\mathrm{t}}=\mathrm{c}+\mathrm{h} \Delta \log \mathrm{F}_{\mathrm{t}}+\varepsilon_{\mathrm{t}}, \varepsilon_{\mathrm{t}} \approx \mathrm{N}(0,1) \text { iid }
$$

$\mathrm{S}_{\mathrm{t}}$ adalah harga spot suatu komoditas pada titik waktu $\mathrm{t}, \mathrm{F}_{\mathrm{t}}$ adalah harga futures suatu komoditas pada titik waktu $t, h$ adalah hedge ratio yang besarnya diestimasi menggunakan metode Ordinary Least Square (OLS). Metode OLS menghasilkan koefisien regresi yang BLUE (Best Linear Unbiased Estimator) apabila error term/residuals memenuhi asumsi $\varepsilon_{\mathrm{t}} \approx \mathrm{N}(0,1)$ iid. Untuk itu, dilakukan uji serial correlation dengan menggunakan Breusch-Godfrey test. Untuk mendeteksi adanya heteroskedasticity di dalam residuals, dilakukan ARCH LM test (Engle, 1982). Engle dan Granger (1987) membuktikan bahwa estimasi regresi antara dua variabel time series keuangan yang umumnya bersifat non stationary memiliki masalah mendasar ditinjau dari sudut teori ekonometrika karena umumnya akan menghasilkan persamaan regresi yang spurious dimana residual bersifat non stationary juga dan melanggar asumsi OLS. Engle dan Granger (1987) juga menunjukkan residual hasil estimasi dari persamaan regresi time series yang non stationary dapat bersifat stationary apabila terdapat hubungan kointegrasi antara time series tersebut. Mereka juga membangun metode uji kointegrasi yang disebut sebagai Engle-Granger Method.

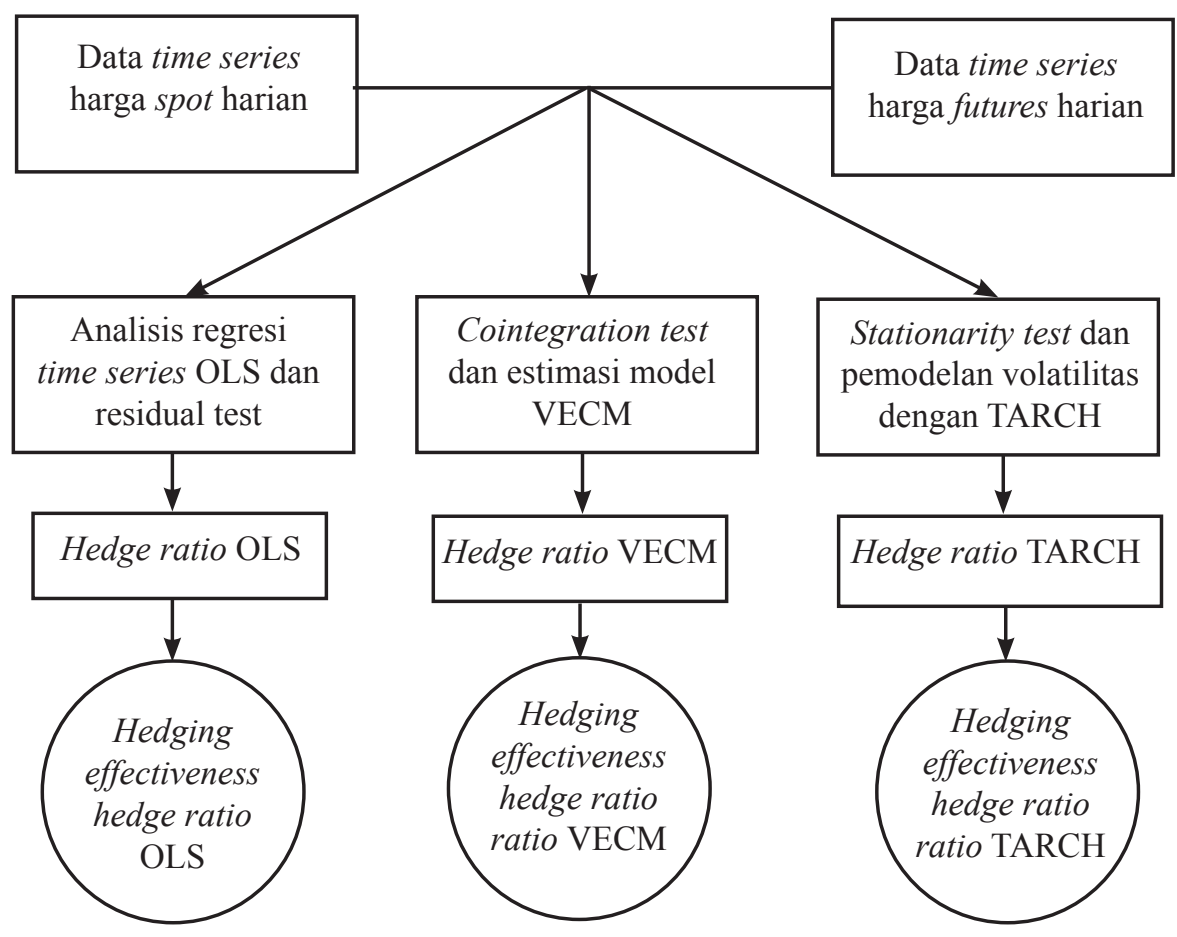

Gambar 2. Kerangka pemikiran penelitian 
Lien (2004) menunjukkan optimal hedge ratio yang diestimasi dengan metode OLS melalui persamaan 5 di atas cenderung terlalu rendah (underestimated) apabila terdapat hubungan kointegrasi antara harga futures dan spot. Kointegrasi perlu dideteksi terlebih dulu apakah ada pada hubungan antara harga futures dan spot dengan menggunakan metode Engle-Granger (Engle and Granger, 1987). Pertama, harga spot dan harga futures diuji terlebih dahulu stasioneritasnya dengan menggunakan Augmented Dickey-Fuller test (Dickey and Fuller, 1981). Seluruh variabel keuangan umumnya tidak stasioner pada data levelnya sehingga memiliki pola pergerakan yang random. Apabila harga futures dan harga spot keduanya bersifat non stasioner dan regresi antara keduanya (persamaan 6) menghasilkan residual yang stasioner maka antara harga futures dan harga spot terdapat hubungan kointegrasi dan persamaan 6 merupakan cointegrating equation. Cointegrating equation mencerminkan hubungan ekuilibrium jangka panjang antara harga futures dan harga spot.

$$
\mathrm{S}_{\mathrm{t}}=\mathrm{c}+\beta \mathrm{F}_{\mathrm{t}}+\varepsilon_{\mathrm{t}}, \varepsilon_{\mathrm{t}} \approx \mathrm{N}(0,1) \text { iid (6) }
$$

Ekuilibrium jangka panjang dapat saja terlanggar dalam jangka pendek, namun disequilibrium selalu akan hilang melalui suatu proses error correction. Model Vector Error Correction memungkinkan kita untuk dapat mengukur kecepatan koreksi error sehingga kembali ke ekuilibrium jangka panjang serta dapat memodelkan hubungan kausalitas yang saling memengaruhi antara harga spot dan harga futures seperti yang ada pada sistem persamaan 7 dan 8 :

$$
\begin{aligned}
\Delta \operatorname{LogS}_{\mathrm{t}}= & \mathrm{c}+\beta \Delta \log \mathrm{F}_{\mathrm{t}}+\sum_{\mathrm{k}} \gamma_{\mathrm{k}} \Delta \log \mathrm{F}_{\mathrm{t}-\mathrm{k}}+\sum_{\mathrm{l}} \delta_{\mathrm{l}} \Delta \log \mathrm{S}_{\mathrm{t}-\mathrm{l}}+\lambda \varepsilon_{\mathrm{t}-} \\
& { }_{1}+\mathrm{u}_{\mathrm{S}, \mathrm{t}}(7) \\
\Delta \operatorname{LogF}_{\mathrm{t}}= & \mathrm{c}+\beta \Delta \log \mathrm{S}_{\mathrm{t}}+\sum_{\mathrm{k}} \gamma_{\mathrm{k}} \Delta \operatorname{LogS}_{\mathrm{t}-\mathrm{k}}+\sum_{\mathrm{l}} \delta_{\mathrm{l}} \Delta \log \mathrm{F}_{\mathrm{t}-\mathrm{l}}+\lambda \varepsilon_{\mathrm{t}-} \\
& +\mathrm{u}_{\mathrm{F}, \mathrm{t}}(8)
\end{aligned}
$$

$\lambda$ adalah speed of adjustment atau kecepatan mekanisme koreksi error menuju ekuilibrium jangka panjang. $\mathrm{u}_{\mathrm{S}, \mathrm{t}}$ dan $\mathrm{u}_{\mathrm{F}, \mathrm{t}}$ adalah vector dari time series residual (innovation) yang dihasilkan dari estimasi sistem persamaan VECM.

Hedge ratio yang dihitung dengan VECM diperoleh melalui persamaan:

$$
h=\frac{\operatorname{Cov}\left(u_{S, t}, u_{F, t}\right)}{\operatorname{Var}\left(u_{F, t}\right)}
$$

$\operatorname{Cov}\left(\mathrm{u}_{\mathrm{S}, \mathrm{t}}, \mathrm{u}_{\mathrm{F}, \mathrm{t}}\right)$ adalah covariance antara $\mathrm{u}_{\mathrm{S}, \mathrm{v}}$, yaitu residual persamaan 7 dan $\mathrm{u}_{\mathrm{F}, \mathrm{t}}$, yaitu residual persamaan 8. Var $\left(\mathrm{u}_{\mathrm{F}, \mathrm{t}}\right)$ adalah varians residual persamaan $8, \mathrm{u}_{\mathrm{F}, \mathrm{t}}$. Hedge ratio dengan model TARCH:

$$
h=\rho_{S, F} \frac{\sigma_{S, t}}{\sigma_{F, t}}
$$

$\rho_{\mathrm{S}, \mathrm{F}}$ adalah koefisien korelasi antara varians harga spot dan futures. $\sigma_{\mathrm{S}, \mathrm{t}}$ dan $\sigma_{\mathrm{F}, \mathrm{t}}$ adalah conditional variance harga spot dan harga futures yang diestimasi dengan model TARCH.

Model Treshhold ARCH (TARCH(1.1)) adalah sebagai berikut:

$$
\sigma_{t}^{2}=c+\beta \varepsilon_{t-1}^{2}+\gamma \varepsilon_{t-1}^{2} I_{t-1}+\theta \sigma_{t-1}^{2}
$$

Untuk mengestimasi conditional variance dari harga spot dan harga futures dengan model TARCH $(1,1)$ digunakan software ekonometrika EViews.

\section{Metode Pengukuran Hedging Effectiveness}

Efektivitas dari sebuah strategi indung nilai adalah berapa besar fluktuasi imbal hasil portfolio yang berisi sejumlah kontrak futures dan posisi kas di pasar spot. Jumlah kontrak futures yang dipegang tergantung dari besarnya hedge ratio yang dihasilkan suatu metode pengukuran. Pada penelitian ini, hedge ratio dihitung dengan tiga metode, yaitu OLS, VECM, dan TARCH. Hedging effectiveness dari ketiga hedge ratio tersebut akan dibandingkan dengan mengukur Hedging Effectiveness masing-masing melalui persamaan berikut ini:

Hedging Effectiveness $=\frac{\text { Variance Unhedged-Variance Hedged }}{\text { Variance Unhedged }}$

Variance Unhedged $=\sigma_{t}^{2}$, varians imbal hasil portfolio yang tidak dilindung nilai akan sama besar dengan varians harga di pasar spot.

Variance of Hedged Portfolio Return dihitung dengan Markowitz's minimum variance portfolio sebagai berikut:

$$
\text { Variance Hedged }=\sigma_{\text {Spot }}^{2}+h^{2} \sigma_{\text {Futures }}^{2}-2 h \sigma_{S F}
$$
$\sigma_{\text {Spot dan }}^{2} h^{2} \sigma_{\text {Futures }}^{2}$ adalah varians harga spot dan varians harga futures; $\mathrm{h}$ adalah hedge ratio; $\sigma_{\mathrm{SF}}$ adalah kovarians antara harga spot dan harga futures. 
Hedging effectiveness dihitung setiap hari pada saat kontrak futures 1 bulan jatuh tempo untuk setiap hedge ratio yang dihitung melalui metode OLS, VECM, dan TARCH. Hedge ratio yang ditetapkan satu bulan sebelumnya yaitu pada saat kontrak futures dibeli dihitung dampaknya kepada volatilitas imbal hasil portfolio.

\section{HASIL}

Hasil estimasi hedge ratio dengan metode estimasi OLS atas persamaan 6 dengan menggunakan seluruh data dapat dilihat pada Tabel 2. Hedge ratio OLS bersifat static sebesar 0,725 .

Tabel 2. Hasil estimasi metode OLS

\begin{tabular}{lcc}
\hline$\Delta \operatorname{LogS}_{\mathrm{t}}=\mathrm{c}+\mathrm{h} \Delta \operatorname{LogF}_{\mathrm{t}}+\varepsilon_{\mathrm{t}}$, & $\varepsilon_{\mathrm{t}} \approx \mathrm{N}(0,1)$ & iid \\
\hline \multicolumn{1}{c}{ Konstanta } & Koefisien & $\mathrm{t}$ test \\
\hline$\Delta \operatorname{LogF}_{\mathrm{t}}$ & 0,34 & $2,12^{* *}$ \\
\hline $\mathrm{R}$ squared & & \\
Durbin Watson Statistics & 0,69 & \\
$\mathrm{~F}$ statistics & 1,72 & \\
\hline
\end{tabular}

Keterangan: *** signifikan pada level of error $1 \%$, ** signifikan pada level of error $5 \%,{ }^{*}$ signifikan pada level of error $10 \%$

Metode pengukuran static hedge ratio dengan menggunakan seluruh data seperti yang ada pada Tabel 2 dikritik oleh Juhl et al. (2012) karena merupakan uji in the sample yang tidak mencerminkan kondisi di lapangan yang dihadapi oleh para praktisi. Juhl et al. (2012) menggunakan rolling windows dengan data yang digunakan untuk mengestimasi hedge ratio yang ditetapkan untuk posisi satu bulan ke depan dengan menggunakan data selama 3 bulan terakhir.

Penelitian ini menggunakan juga metode rolling windows seperti yang diusulkan oleh Juhl et al. (2012). Berbeda dengan metode statis OLS pada Tabel 2 dimana hedge ratio bersifat konstan sebesar 0,725 , metode rolling windows menghitung hedge ratio setiap bulan dengan menggunakan data tiga bulan sebelumnya dan kemudian menghitung hegding effectiveness dari semua hedging ratio tersebut dengan masa jatuh tempo satu bulan. Jadi setiap awal bulan ditentukan sebuah hedge ratio kemudian dihitung seberapa besar volatilitas imbal hasil portfolio dapat dikurangi dengan menggunakan hedge ratio tersebut. Rata-rata dan varians dari hedge ratio bulanan dengan metode OLS pada Tabel 3 .
Tabel 3. Statistik deskriptif hedge ratio dengan metode OLS

\begin{tabular}{lccccc}
\hline & $\begin{array}{l}\text { Rata- } \\
\text { rata }\end{array}$ & $\begin{array}{l}\text { Standard } \\
\text { Deviation }\end{array}$ & Median & Max & Min \\
\hline $\begin{array}{l}\text { Hedge } \\
\text { Ratio }\end{array}$ & 0,77 & 0,11 & 0,68 & 0,81 & 0,65 \\
\hline
\end{tabular}

Uji serial correlation dengan Breusch Godfrey LM test atas error term persamaan 6 yang diestimasi dengan metode OLS menunjukkan adanya korelasi serial yang cukup kuat. ARCH LM test juga menunjukkan adanya heteroskedastisitas. Uji Breusch Godfrey dan ARCH LM Test dapat dilihat pada Tabel 4. Adanya korelasi serial dan ARCH effect pada error term menunjukkan terlanggarnya asumsi klasik OLS yang menyebabkan hasil estimasi koefisien regresi dengan metode OLS berpotensi untuk bias dan tidak efisien. Masalah ini seringkali muncul pada regresi time series yang membuat estimasi hedge ratio dengan metode OLS sering disebut sebagai metode yang "naïve"

Tabel 4. Uji korelasi derial dan ARCH effect

\begin{tabular}{ll}
\hline $\begin{array}{l}\text { Breusch Godfrey Serial } \\
\text { correlation LM Test }\end{array}$ & \\
\hline F Statistics & $3,792^{* *}$ Prob : 0,0032 \\
Obs x R squared & $14,987^{*}$ Prob : 0,057 \\
\hline Harvey ARCH LM & \\
Heteroskedasticity test & \\
\hline F Statistics & $4,887^{* * *}$ Prob : 0,0002 \\
Obs x R squared & $18,568^{* *}$ Prob : 0,037 \\
\hline
\end{tabular}

Keterangan: $* * *$ signifikan pada level of error $1 \%$, ** signifikan pada level of error $5 \%,{ }^{*}$ signifikan pada level of error $10 \%$

Hedge ratio dengan metode VECM diperoleh dengan terlebih dahulu menguji stationaritas time series harga spot dan harga futures. Table 5 menunjukkan kedua data runtun waktu tersebut tidak stationer pada data level. Namun, keduanya stasioner pada first difference.

Untuk menguji adanya hubungan cointegration antara harga spot dan harga futures dilakukan uji kointegrasi dengan metode Engle-Granger yaitu dengan menguji apakah residual yang dihasilkan dari regresi harga spot dan harga futures terbukti bersifat stationary. Tabel 6 menunjukkan residual bersifat stationary sehingga dapat dikatakan ada hubungan kointegrasi antara harga spot dan harga futures. 
Tabel 5. Uji stasioneritas harga spot dan harga futures

\begin{tabular}{lc}
\hline & Augmented Dickey-Fuller Test \\
\hline Level & t. Value \\
Harga Spot & 1,521 \\
Harga Futures & 1,587 \\
First Difference & \\
Harga Spot & $13,478^{* * *}$ \\
Harga Futures & $21,429^{* * *}$ \\
\hline
\end{tabular}

Keterangan: *** signifikan pada level of error $1 \%$, ** signifikan pada level of error $5 \%,{ }^{*}$ signifikan pada level of error $10 \%$

Tabel 6. Uji kointegrasi dengan metode Engle-Granger Augmented Dickey-Fuller Test t value

\begin{tabular}{ll} 
& Augmented Dickey-Fuller Test \\
\hline & $t$ value \\
\hline Residual & $8,361^{* * *}$ \\
\hline
\end{tabular}

Karena terbukti ada hubungan kointegrasi maka persamaan 6 merupakan cointegrating equation yang menunjukkan hubungan ekuilibrium jangka panjang antara harga spot dan harga futures. Rata-rata dan varians dari hedge ratio bulanan dengan metode VECM menggunakan rolling windows 3 bulan dapat dilihat pada Tabel 7.

Hasil estimasi volatilitas harga spot dan harga futures dengan model TARCH dengan menggunakan data 3 tahun serta rata-rata hedge ratio yang diukur dengan model ARCH dapat dlihat pada Tabel 8 dan Tabel 9.

Signifikannya koefisien $\gamma$ yang menunjukkan tingkat keparahan asimetrik dari volatilitas atau yang biasa disebut sebagai leverage membawa ke kesimpulan bahwa volatilitas harga futures dan spot bersifat asimetrik. Besarnya volatilitas harga future dan spot berbeda pada saat kondisi pasar bearish dan bullish. Hedging effectiveness dari implementasi hedge ratio yang diestimasi dengan metode OLS, VECM dan TARCH dapat dilihat pada Tabel 10. Efektivitas lindung nilai dengan ketiga metode penentuan hedge ratio cukup tinggi di Bursa Berjangka Jakarta. Semua metode menghasilkan penurunan volatilitas sekitar $70 \%$. Volatilitas imbal hasil portfolio kas di pasar spot dan kontrak futures jauh lebih rendah dibandingkan dengan strategi tanpa lindung nilai dengan cara langsung membeli di pasar spot.

Efektivitas lindung nilai dengan metode penentuan hedge ratio dengan VECM paling tinggi dibandingkan dua metode lainnya, OLS dan TARCH, tetapi perbedaan efektivitas lindung nilai nya dengan metode OLS tidak terlampau besar. Metode TARCH yang paling kompleks memberikan efektivitas yang terendah. Melihat kompleksitas prosedur estimasi model VECM dan TARCH, efektivitas lindung nilai dengan metode OLS menjadi sangat menarik. Temuan di bursa berjangka Jakarta ini hampir mirip dengan yang ditemukan oleh beberapa peneliti lain seperti Lien (2005) dan Gupta dan Singh (2009).

Strategi hedging dengan menggunakan metode penentuan hedge ratio yang sederhana seperti regresi OLS. Namun, justru memiliki hedging effectivenes yang lebih tinggi dibandingkan apabila menggunakan metode lain yang lebih kompleks seperti yang ditemukan di Bursa Berjangka Jakarta ini ditemukan pertama kali oleh Moschini dan Myers, 2002). Permasalahan teknis dari sudut ekonometrika seperti adanya hubungan kointegrasi dan volatilitas yang bersifat asimetrik ternyata tidak membuat efektivitas lindung nilai yang didasarkan pada besaran hedge ratio OLS menjadi jauh di bawah efektivitas hedging yang dapat dihasilkan melalui hedge ratio yang diestimasi dengan metode ekonometri yang lebih canggih. Hal yang hampir mirip ditemukan juga oleh Gupta dan Kaur (2015) di India, Bhargava dan Malhotra (2007) di beberapa negara Asia, dan Lien (2005) di Amerika Serikat dan beberapa negara Eropa. Juhl et al. (2012) menunjukkan efektivitas lindung nilai dalam jangka pendek lebih tinggi dengan menggunakan metode penentuan hedge ratio yang lebih sederhana. Efektivitas lindung nilai untuk jangka waktu lebih panjang, misalnya tiga dan enam bulan, diduga akan sangat dipengaruhi oleh adanya hubungan kointegrasi, mengingat kointegrasi adalah pola hubungan jangka panjang antara fluktuasi harga spot dan harga futures. Temuan ini sekaligus memperkuat temuan sebelumnya bahwa dengan jangka waktu hedging yang relatif pendek seperti satu bulan yang diuji pada penelitian ini, efektivitas hedging tidak terlampau dipengaruhi oleh adanya hubungan kointegrasi antara harga spot dan harga futures.

Temuan dari penelitian ini juga sejalan dengan Lien (2004) yang menunjukkan optimal hedge ratio yang diestimasi dengan metode OLS melalui persamaan 5 cenderung terlalu rendah (underestimated) apabila terdapat hubungan kointegrasi antara harga futures dan spot. Hedge ratio dengan metode OLS cenderung lebih rendah dibandingkan dengan metode VECM karena adanya hubungan kointegrasi antara harga spot dan futures. Namun, hedging effectiveness yang 
hanya berselisih sebesar 3\% antara OLS dan VECM seperti yang dapat dilihat pada Tabel 10, maka dapat disimpulkan adanya hubungan kointegrasi tidak terlampau memengaruhi kinerja hedge ratio OLS sebagai dasar penerapan strategi lindung nilai apabila dibandingkan dengan VECM. Tipisnya perbedaaan hedging effectiveness antara OLS dan VECM di Bursa Berjangka Jakarta diduga karena likuiditas di pasar futures yang masih relatif dangkal. Transaksi kontrak futures di Bursa Berjangka Jakarta masih relatif rendah di bandingkan dengan Bursa Malaysia. Seperti yang ditunjukkan pula oleh Alizadeh dan Nomikos (2004) bahwa setiap tahap perkembangan pasar komoditas berjangka membutuhkan strategi penentuan hedge ratio yang berbeda.

Tabel 7. Statistik deskriptif hedge ratio dengan model VECM

\begin{tabular}{lccccc}
\hline & $\begin{array}{l}\text { Rata- } \\
\text { rata }\end{array}$ & $\begin{array}{c}\text { Standard } \\
\text { Deviation }\end{array}$ & Median & Max & Min \\
\hline $\begin{array}{l}\text { Hedge } \\
\text { Ratio }\end{array}$ & 0,79 & 0,08 & 0,69 & 0,809 & 0,75 \\
\hline
\end{tabular}

Tabel 8. Hasil estimasi volatilitas harga spot dan harga futures dengan model TARCH

\begin{tabular}{ll}
\hline Koefisien & Hasil Estimasi (t value) \\
\hline Harga Futures & \\
$\mathrm{c}$ & $0,13(1,98)^{*}$ \\
$\beta$ & $0,68(2,53)^{*}$ \\
$\gamma$ & $0,15(2,14)^{* *}$ \\
$\theta$ & $0,75(1,89)^{*}$ \\
Harga Spot & \\
$\mathrm{c}$ & $0,19(1,56)^{*}$ \\
$\beta$ & $0,68(2,09)^{*}$ \\
$\gamma$ & $0,21(2,23)^{* *}$ \\
$\theta$ & $0,65(1,77)^{*}$ \\
\hline Keterangan: *** signifikan pada level of error $1 \%, * *$ \\
signifikan pada level of error $5 \%,{ }^{*}$ signifikan pada level of \\
error $10 \%$
\end{tabular}

Tabel 9. Statistik deskriptif hedge ratio dengan model TARCH

\begin{tabular}{lccccc}
\hline & $\begin{array}{l}\text { Rata- } \\
\text { rata }\end{array}$ & $\begin{array}{c}\text { Standard } \\
\text { Deviation }\end{array}$ & Median & Max & Min \\
\hline $\begin{array}{l}\text { Hedge } \\
\text { Ratio }\end{array}$ & 0,63 & 0,27 & 0,79 & 0,89 & 0,48 \\
\hline
\end{tabular}

Tabel 10. Hedging Effectiveness

\begin{tabular}{lc}
\hline Hedge Ratio & Hedging Effectiveness \\
\hline OLS & 0,75 \\
VECM & 0,78 \\
TARCH & 0,68 \\
\hline
\end{tabular}

\section{Implikasi Manajerial}

Implikasi secara teoretis dari temuan penelitian ini adalah hedge ratio OLS di pasar yang tidak likuid seperti yang ada di pasar futures Indonesia akan lebih rendah dibandingkan hedge ratio yang diestimasi dengan metode ekonometrika yang lebih canggih seperti VECM dan TARCH. Namun, efektivitas lindung nilai dengan menggunakan hedge ratio OLS tidak terlampau jauh dibandingkan yang dihasilkan oleh hedge ratio lain yang lebih canggih apabila digunakan untuk hedging dalam jangka waktu yang relatif pendek seperti satu bulan.

Cukup tingginya efektivitas lindung nilai yang dapat diperoleh dengan strategi membeli kontrak futures olein di Bursa Berjangka Jakarta memberikan kesempatan kepada semua pihak yang berkepentingan, baik produsen maupun konsumen, untuk melindungi diri dari fluktuasi harga olein di pasar spot. Penentuan hedge ratio dapat dilakukan secara relatif mudah yaitu dengan metode regresi OLS antara perubahan harga futures dan harga spot. Penelitian ini membuktikan efektivitas lindung nilai dengan metode OLS tidak terlampau terpaut jauh dengan metode penentuan hedge ratio yang lebih canggih seperti VECM dan TARCH.

Strategi lindung nilai yang dibuktikan dalam penelitian ini adalah strategi lindung nilai yang bersifat berkelanjutan dengan mengambil posisi di pasar futures setiap hari untuk kontrak pengiriman 1 bulan ke depan. Implementasi strategi dengan interval waktu yang lebih panjang dan dengan masa kontrak yang lebih lama membutuhkan perhitungan hedging effectiveness tersendiri yang disesuaikan dengan kebutuhan spesifik setiap orang. Seperti yang ditekankan oleh Lien (2005), penggunaan metode OLS cenderung lebih baik pada implementasi lindung nilai dengan interval pendek dan masa kontrak jangka pendek, misalnya bulanan. Apabila ada hubungan kointegrasi antara harga spot dan harga futures, strategi hedging untuk posisi jangka menengah dan panjang dengan metode VECM diduga akan memberikan hedging effectiveness yang jauh 
lebih tinggi karena adanya hubungan kointegrasi menunjukkan adanya hubungan ekuilibrium jangka panjang antara harga spot dan harga futures.

\section{KESIMPULAN DAN SARAN}

\section{Kesimpulan}

Efektivitas lindung nilai olein atau minyak sawit dengan mengambil posisi di pasar futures Jakarta cukup tinggi. Bursa Berjangka Jakarta memberikan peluang lindung nilai yang cukup baik dimana posisi di kontrak futures dapat menurunkan volatilitas imbal hasil portfolio sampai lebih dari $70 \%$ dibandingkan apabila tidak menggunakan lindung nilai dengan bertransaksi secara kas di pasar spot. Tiga metode penentuan hedge ratio, OLS, VECM dan TARCH, memiliki efektivitas lindung nilai yang tidak terlampau terpaut jauh. VECM menghasilkan hedging effectiveness yang tertinggi. Tinggi nya efektivitas lindung nilai dengan VECM disebabkan adanya hubungan kointegrasi antara harga spot dan harga futures di Bursa Berjangka Jakarta. Hedging dalam jangka menengah dan panjang sebaiknya menggunakan strategi yang didasarkan pada hedge ratio VECM. Tantangan terbesar dari implementasi hedge ratio VECM adalah penguasaan teori dan model ekonometrika kointegrasi dan pemodelan ekonometrika VECM menggunakan software ekonometrika yang ada.

Efektivitas lindung nilai dengan hedge ratio OLS yang cukup tinggi dan tidak terlampau terpaut jauh dengan yang dihasilkan oleh hedge ratio dengan metode yang lebih canggih memberikan peluang yang cukup baik atas implementasi strategi hedging di Bursa Berjangka Jakarta karena relatif mudahnya menjalankan metode OLS tanpa perlu memahami terlebih dahulu konsep ekonometrika yang cukup canggih seperti kointegrasi dan asimetric volatility ARCH. Untuk mengestimasi hedge ratio bahkan tidak memerlukan software ekonometrika, cukup dengan aplikasi spreadsheet yang dikuasai secara luas oleh kalangan awam ekonometrika besarnya hedge ratio dengan metode OLS sudah dapat diperoleh dengan mengestimasi persamaan regresi sederhana antara perubahan harga spot dan perubahan harga futures. Namun, implementasi metode OLS perlu dijalankan secara berhati-hati karena dari hasil penelitian ini dapat dibuktikan adanya hubungan kontegrasi antara harga futures dan harga spot serta bersifat asimetriknya volatilitas harga spot dan harga futures. Kointegrasi dan volatilitas yang asimetrik dapat menyebabkan hedge ratio yang tidak akurat untuk posisi hedging dalam jangka panjang.

\section{Saran}

Penelitian selanjutnya dapat fokus pada pengungkapan faktor-faktor apa saja yang memengaruhi kinerja setiap hedge ratio, seperti likuiditas pasar komoditas berjangka, dan kondisi makroekonomi. Metode estimasi hedge ratio dapat dikembangkan lebih jauh untuk dapat menangkap lebih tajam volatilitas yang asimetrik dan uji kointegrasi dengan menggunakan metode uji yang lebih robust.

\section{DAFTAR PUSTAKA}

Alizadeh A, Nomikos N. 2004. A Markov Regime Switching approach for hedging stock indices. The Journal of Futures Market 24 (7): 649-674. https://doi.org/10.1002/fut.10130.

Bellemare MF. 2011. Rising food prices, food price volatility, and social unrest. American Journal of Agricultural Economics 97(1): 1-21. https://doi. org/10.1093/ajae/aau038.

Bhargava V, Malhotra D. 2007. Determining the optimal hedge ratio: Evidence from cotton and soybean markets. Journal of Business and Economic Studies 13(1): 38-57

Cotter J, Hanly J. 2012. Hedging effectiveness under conditions of asymmetry. The European Journal of Finance 18(2): 2012. https://doi.org/10.1080/ $1351847 X .2011 .574977$.

Dickey D, Fuller F. 1981. Likelihood Ratio Statistics for autoregressive time series with a unit root. Econometrica 49:1057-1072 https://doi. org/10.2307/1912517.

Engle R. 1982. Autoregressive Conditional Heteroskedasticity With estimates of the variance of UK Inflation. Econometrica 50 (1982): 9871008. https://doi.org/10.2307/1912773.

Engle R, Granger C.1987. Co-integration and Error Correction: Representation, estimation and testing. Econometrica 55(1): 251-276. https:// doi.org/10.2307/1913236.

Fatimah M, Zainalabidin M. 1991. Forecasting Ability of Malaysian Crude Palm Oil Futures Price on Physical Price. Kuala Lumpur: PORIM International Palm Oil Conference, Palm Oil Research Institute of Malaysia, Kuala Lumpur. 
Galtier F. 2013. Managing food price instability in developing countries A critical analysis of strategies and instruments, Agence Française de Développement CIRAD-DIST.

Gupta K, Singh B. 2009. Estimating the optimal hedge ratio in Indian equity futures market. Journal of Financial Risk Management 7(3 ): 38-98.

Juhl T, Kawaller I, Koch P. 2012. The Effect of the hedge horizon on optimal hedge size and effectiveness when prices are cointegrated. The Journal of Futures Markets 32(9): 837-876. https://doi. org/10.1002/fut.20544.

[Kemendag RI] Kementerian Perdagangan Republik Indonesia. 2016. Monthly Trade Figure Indonesia, 2012 -2016, Jakarta: Kemendag RI.

$\mathrm{Ku}, \mathrm{Y}, \mathrm{Chen}, \mathrm{H}, \mathrm{Chen}, \mathrm{H} .2007$. On the application of the dynamic conditional correlation model in estimating optimal timevarying hedge ratios. Applied Economics Letters 14: 503-509. https:// doi.org/10.1080/13504850500447331.

Lien D. 2005. A Note on the superiority of the OLS hedge ratio. The Journal of Futures Markets 25(11):1121-1126.https://doi.org/10.1002/ fut. 20172 .

Lien D. 2004. Cointegration and the optimal hedge ratio: The general case. The Quarterly Review of Economics and Finance 44(5): 654-658. https:// doi.org/10.1016/j.qref.2003.08.004.
Liew K, Brooks R. 1998. Returns and volatility in the Kuala Lumpur crude palm oil futures market. Journal of Futures Markets 18(8):985-999.https://doi.org/10.1002/ (SICI)1096-9934(199812)18:8<985::AIDFUT6 $>3.0 . \mathrm{CO} ; 2-5$.

Moschini G, Myers R. 2002. Testing for constant hedge ratios in commodity markets: a multivariate GARCH approach. Journal of Empirical Finance 9: 589-603. https://doi.org/10.1016/ S0927-5398(02)00012-9.

Roache S. 2010. What explains the rise in food price volatility? IMF Working Papers 10(129): 1-29.

Rosalan bin Ali. 1995. Forecasting and hedging: An illustration of risk reduction and profit opportunities in the global palm oil industry [dissertation]. Dublin:University of College Dublin,

Wright B. 2011. The economics of grain price volatility. applied economic perspectives and policy 33(1): 32-58. https://doi.org/10.1093/aepp/ppq033.

Yang W, Allen D. 2005. Multivariate GARCH hedge ratios and hedging effectiveness in Australian futures markets, Journal of Accounting \& Finance 45(2): 301-321. https://doi.org/10.1111/ j.1467-629x.2004.00119.x. 